\title{
Pengembangan Perangkat Pembelajaran Biologi SMP Untuk Meningkatkan Prestasi Belajar Dan Melatih Kemandirian Siswa Melalui Pendekatan Keterampilan Proses Sains
}

\author{
Armansyah Putra \\ e-mail : arman091088@gmail.com
}

\begin{abstract}
Abstrak : Penelitian ini secara umum bertujuan untuk mengembangkan perangkat pembelajaran biologi SMP untuk meningkatkan prestasi belajar dan tingkat kemandirian siswa melalui Pendekatan Keterampilan Proses Sains materi pokok gerak tumbuhan. Jenis penelitian ini adalah penelitian pengembangan mengacu pada model pengembangan Kemp. Penelitian ini diawali dengan mengembangkan perangkat pembelajaran biologi untuk SMP. Penerapan perangkat pembelajaran biologi bertujuan untuk mendeskripsikan keterlaksanaan perangkat, aktivitas siswa, respon siswa, hasil belajar, kemandirian dan hambatan-hambatan selama proses pembelajaran. Perangkat pembelajaran tersebut diimplementasikan pada siswa kelas VIII SMPN 1 Blega Bangkalan Madura dengan menggunakan pendekatan Keterampilan Proses Sains sebanyak 28 siswa. Implementasi perangkat menggunakan One Group Pretest-Postest Design dan data dianalisis secara deskriptif kualitatif.

Hasil penelitian menunjukkan bahwa Keterlaksanaan perangkat pembelajaran sebesar 83\%, aktivitas belajar siswa yang dominan pada pertemuan pertama dan kedua adalah melakukan pengamatan sebesar $22 \%$ hingga $24 \%$, respon siswa sebesar $99 \%$ menyatakan senang artinya sebagian besar siswa memberikan respon yang positif, ketuntasan hasil belajar siswa secara kelasikal sebesar $86 \%$, dengan tingkat kemandirian siswa bervariasi mulai dari $55,56 \%$ hingga $83,32 \%$, dan hambatan-hambatan yang ditemui selama proses pembelajaran adalah banyak siswa yang belum mengenal penggunaan alat, minimnya alat dan bahan yang tersedia, presentasi siswa kurang siap dan kurangnya pemahaman siswa tentang konsep presentasi.

Berdasarkan hasil analisis data menyatakan bahwa Pengembangan Perangkat Pembelajaran Biologi SMP Untuk Meningkatkan Prestasi Belajar dan Melatih Kemandirian Siswa Melalui Pendekatan Keterampilan Proses Sains layak untuk digunakan
\end{abstract}

Kata-kata Kunci: Prestasi belajar, Kemandirian, Pendekatan Keterampilan Proses sains.

Abstract : This research is aimed to develop biology learning materials in Junior High School for plants movement topic to increase students' achievement and self-help through Science Process Skill approach. This is development research refers to Kemp's development model. This research begins with developing biology learning kit for Junior High School. The applied of biology learning kit aims to describe the implementation of learning kit, students' activity, students' response, result of learning (achievement), self-help, and obstacles during learning process. The learning kit is taught in SMPN 1 Blega Bangkalan Madura for 28 students grade VIII employing science process skill approach. The research design uses One Group Pretest-Posttest and data is analysed with qualitative descriptive method.

This research reveals that the implementation of learning kit is $83 \%$, dominant students activities in $1^{\text {st }}$ and $2^{\text {nd }}$ learning process are observing $(22 \%-24 \%)$, most of the students have positive responses which is indicated by $99 \%$ of students expressing their like, the result of students' learning mastery satisfies the classical criteria for $86 \%$, the rate of students self-help varies from $55,56 \%$ to $83,32 \%$, 
and the obstacles faced in learning are: many students are unfamiliar with the usage of equipment, the lack of equipment and substances, the students are not ready for presentation and the students have minor understanding about the concept of presentation.

Based on the data analysis, it can be concluded that the Development of Biology Learning Kit for Junior High School to Increase Students' Achievement and Self-help through Science Process Skill Approach is feasible.

Key words: Achievement, Self-help, Science Process skill, approach

\section{PENDAHULUAN}

Percepatan arus informasi dalam era globalisasi dewasa ini menuntut semua bidang kehidupan untuk menyesuaikan visi, misi, tujuan dan strategi agar sesuai dengan kebutuhan dan tidak ketinggalan zaman. Penyesuaian tersebut secara langsung mengubah tatanan dalam sistem makro, meso, maupun mikro, demikian halnya dalam sistem pendidikan. Sistem pendidikan Nasional senantiasa harus dikembangkan sesuai dengan kebutuhan dan perkembangan yang terjadi baik di tingkat lokal, Nasional maupun global (Mulyasa, 2006).

Prestasi belajar adalah gambaran tingkat pengetahuan atau kemampuan siswa terhadap suatu materi pembelajaran yang sudah dipelajari dan dapat digunakan sebagai bekal atau modal untuk memperoleh pengetahuan yang lebih luas dan kompleks lagi, maka dapat disebut sebagai kemampuan akademik. Musrofi (2010) mengemukakan bahwa secara alami dalam satu kelas Prestasi belajar siswa bervariasi, jika dikelompokkan menjadi 3 kelompok, maka ada kelompok siswa berkemampuan tinggi, menengah, dan rendah. Apabila siswa memiliki tingkat kemampuan berbeda kemudian diberi pengajaran yang sama, maka hasil belajar (pemahaman konsep) akan berbeda-beda sesuai dengan tingkat kemampuannya, karena hasil belajar berhubungan dengan kemampuan siswa dalam mencari dan memahami materi yang dipelajari.

Sedangkan belajar mandiri (kemandirian) bukan berarti belajar sendiri, melainkan suatu prinsip belajar yang bertumpu pada kegiatan dan tanggung jawab siswa itu sendiri ntuk keberhasilan belajarnya. Melainkan suatu kegiatan belajar aktif yang didorong oleh motif untuk menguasai sesuatu kompetensi, dan dibangun dengan bekal pengetahuan atau kompetensi yang telah dimiliki yang dilakukan oleh pembelajar sendiri. Pendidikan sains (IPA) berperan penting dalam pembentukan kepribadian dan perkembangan intelektual siswa/anak didik. Melalui berbagai upaya yang dilakukan, pendidikan sains senantiasa mengalami pengkajian ulang dan pembaharuan untuk mencari bentuknya yang lebih sesuai.

Pelaksanaan proses belajar mengajar harus diperhatikan kondisi dan keadaan siswa dalam menerima materi baik itu Instruction systems (sistem pengajaran), Instruction systems design (perancangan sistem 
pengajaran), Instruction systems development (pengembangan sistem pengajaran), Learning systems design (perancangan sistem belajar), Competency-based instruction (pengajaran berdasarkan kemampuan), Criterion-referenced instruction (pengajaran beracuan-patokan) dan Performance technology (teknologi kerja). (Kemp, 1994)

Pendidikan sains (IPA) berperan penting dalam pembentukan kepribadian dan perkembangan intelektual siswa/anak didik. Melalui berbagai upaya yang dilakukan, pendidikan sains senantiasa mengalami pengkajian ulang dan pembaharuan untuk mencari bentuknya yang lebih sesuai. Pembaharuan dan pengembangan pendidikan IPA diupayakan dengan melihat kesesuaian dengan hakikat IPA itu sendiri serta perkembangan anak (siswa). Penyesuaian ini tentu saja akan membawa warna dalam praktik pendidikan IPA (Pembelajaran IPA) di lingkungan pendidikan formal (sekolah), disamping itu Keterampilan Proses Sains dinilai kurang berkembang karena dalam pembelajaran siswa cendarung tidak terlibat dengan obyek yang kongkret, padahal keterampilan proses sangat dibutuhkan dalam bekerja ilmiah karena mendasari langkah siswa pada pemecahan masalah yang akhirnya akan membawa siswa pada kemampuan yang diharapkan. (Widayanto, 2009).
Untuk mengatasi kondisi di atas maka diperlukan suatu pendekatan, pembelajaran yang sesuai untuk mengembangkan karakter, meningkatkan prestasi belajar dan keterampilan proses sains siswa. Salah satu pendekatan yang dapat digunakan adalah pendekatan Keterampilan Proses Sains. Padilla, okey dan Garrard (1984) menyatakan bahwa: " The integrated science process skill can help students become inquirers and problem solvers because they provide students with the conceptual tool to engage in investigations and to identify a problem, design a procedure, and find a solutions". Keterampilan proses sains merupakan pendekatan pembelajaran berbasis inkuiri yang mana siswa diberikan suatu masalah untuk dipecahkan, atau seperangkat pengamatan untuk menjelaskan, kemudian siswa bekerja sebagian besar dalam suatu pola atau cara yang diatur oleh siswa itu sendiri di dalam proses menyelesaikan tugastugas yang diberikan dan menggambarkan inferensi hasil penemuan pengetahuan faktual dan konseptual (Haryono, 2006).

\section{METODE PENELITIAN}

Penelitian ini diawali dengan pengembangan perangkat dengan menggunakan pengembangan model Kemp. Kemudian perangkat yang telah di kembangkan diterapkan pada satu kelas saja, yaitu kelas VIIIF SMPN 1 Blega Bangkalan Madura. Subyek penelitian Pada tahap pengembangan adalah perangkat 
pembelajaran biologi SMP untuk meningkatkan prestasi belajar dan melatih kemandirian siswa melalui Pendekatan Keterampilan Proses Sains pada pokok bahasan gerak pada tumbuhan. Sedangkan subjek penelitian pada tahap implementasi adalah siswa kelas VIII SMPN 1 Blega Bangkalan Madura, semester II tahun ajaran 2011/2012.

Dalam kegiatan penelitian ini, implementasi di kelas menggunakan One Group Pretest-Postest Design (Tuckman, 1978) polanya adalah:

$\begin{array}{ccc}\text { Uji awal } & \text { Perlakuan } & \text { Uji akhir } \\ \mathrm{O}_{1} & \mathrm{X} & \mathrm{O}_{2}\end{array}$

\section{Keterangan:}

$\mathrm{O}_{1}=$ Memberikan uji awal, untuk merekam penguasaan siswa terhadap topik gerak pada tumbuhan sebelum diberikan perlakuan.

$\mathrm{X}=$ Memberikan perlakuan pada siswa, yaitu dengan menggunakan perangkat pembelajaran materi gerak pada tumbuhan dengan Pendekatan Keterampilan Proses Sains yang telah dikembangkan.

$\mathrm{O}_{2}=$ Memberikan uji akhir $\mathrm{O}_{2}$, untuk merekam penguasaan siswa terhadap topik gerak pada tumbuhan setelah diberikan perlakuan.

Instrumen yang dikembangkan dan digunakan dalam penelitian ini adalah sebagai berikut:
1. Lembar Validasi Perangkat

Validasi adalah kesesuaian, kebermaknaan, dan kebermanfaatan inferensi yang didasarkan pada proses pengumpulan bukti (evidence) untuk menunjang inferensi (Ibrahim,2005). Instrumen ini digunakan untuk menilai kelayakan komponen perangkat yang dikembangkan.

2. Lembar Pengamatan Keterlaksanaan Pembelajaran

Instrumen ini digunakan untuk menilai keterlaksanaan langkah-langkah pembelajaran biologi SMP dengan menggunakan Pendekatan Keterampilan Proses Sains.

\section{Lembar Pengamatan Aktivitas Siswa} Lembar pengamatan aktivitas siswa ini, digunakan untuk mengamati aktivitas siswa selama proses kegiatan belajar mengajar.

4. Lembar pengamatan Respon siswa Instrumen ini digunakan untuk mengetahui pendapat siswa tentang pembelajaran dengan Pendekatan Keterampilan Proses Sains.

\section{Lembar Penilaian Prestasi belajar} Merupakan instrumen untuk mengukur kemampuan prestasi belajar siswa. Meliputi kisi-kisi tes tertulis (dalam tabel spesifikasi), lembar tes tertulis berisi butirbutir soal untuk mengevaluasi sekaligus mengukur hasil belajar siswa secara tertulis. Bentuk dari tes ini adalah tes 
pilihan ganda dan tes uraian. Analisis instrumen tes pada penelitian ini meliputi analisi reliabilitas tes, dan analisis sensivitas butir soal.

\section{Reliabilitas Tes}

Terkait dengan bentuk soal yang berbeda maka untuk analisis reliabilitas tes prestasi belajar menggunakan dua metode pengujian yaitu metode pengujian reliabilitas menggunakan teknik non belah dua formula KR-20, dan mengunakan formula Alpha. Formula KR-20 digunakan untuk menganailis bentuk butir soal pilihan ganda sedangkan formula Alpha digunakan untuk menganalisis soal bentuk uraian.

1) Reliabilitas instrumen tes pilihan ganda Pengujian reliabilitas soal pilihan ganda dianalisis menggunakan teknik non-belah dua dikembangkan oleh Kuder dan Richardson dengan mengunakan rumus KR-20

$$
r_{11}=\left(\frac{n}{n-1}\right)\left(\frac{s_{t}^{2}-\Sigma p_{i} q_{i}}{s_{t}^{2}}\right)
$$

(Ratumanan \& Lauren, 2006)

\section{Keterangan:}

$\mathrm{n}=$ banyaknya butir soal

$\mathrm{p}_{\mathrm{i}}=$ proporsi banyak subjek yang menjawab benar butir soal ke-1

$\mathrm{q}_{\mathrm{i}}=$ proporsi banyak subjek yang menjawab salah butir soal ke- 1

2) Reliabilitas instrumen tes uraian
Untuk mencari koefisien reliabilitas instrumen tes uraian, digunakan rumus Alpha.

$$
\propto=r_{11}=\left(\frac{n}{n-1}\right)\left(1-\frac{\sum k_{i}^{2}}{s_{t}^{2}}\right)
$$

(Ratumanan \& Lauren, 2006)

\section{Keterangan:}

$\mathrm{N}$ = Banyaknya butir soal

$\Sigma s_{i}^{2}=$ Jumlah varians skor setiap item

$s_{t}^{2} \quad=$ Varians skor total

Kriteria yang digunakan untuk menetapkan tingkat reliabilitas butir soal didasarkan pada indeks kriketria reliabilitas instrumen berikut;

\begin{tabular}{|c|c|}
\hline Kooefisien Reliabilitas & Penafsiran \\
\hline $0,80 \leq \mathrm{r}$ & $\begin{array}{c}\text { Derajat reliabilitas } \\
\text { tinggi }\end{array}$ \\
\hline $0,40 \leq \mathrm{r}<0,80$ & $\begin{array}{c}\text { Derajat reliabilitas } \\
\text { sedang }\end{array}$ \\
\hline $\mathrm{r}<0,40$ & $\begin{array}{c}\text { Derajat reliabilitas } \\
\text { rendah }\end{array}$ \\
\hline
\end{tabular}

(Ratumanan \& Lauren, 2006)

b) Sensitivitas butir soal

Guna memperoleh ukuran keefektifan item berdasarkan hasil pembelajaran, guru harus memberikan tes yang sama sebelum dan sesudah pembelajaran. item-item yang efektif akan dijawab benar oleh sejumlah lebih besar siswa sesudah pembelajaran dari pada sebelum pembelajaran.

Ukuran sensitivitas suatu butir soal pada dasarnya merupakan ukuran berapa baik butir soal itu dapat 
membedakan antara siswa yang telah menerima pembelajaran dan yang belum. Untuk menghitung sensitivitas butir soal digunakan rumus sebagai berikut :

$$
s=\frac{R_{a}-R_{b}}{T}
$$

(Gronlund, 1985)

\section{Keterangan:}

$\mathrm{Ra}=$ Banyak Siswa yang menjawab benar pada tes akhir

$\mathrm{Bb}=$ Banyak siswa yang menjawab benar pada tes awal

$\mathrm{T}$ = Banyak siswa yang megikuti tes

Indeks sensitivitas butir soal berada di antara 0,00 dan 1. Indeks yang lebih besar menunjukkan tingkat sensitivitas tinggi, sedang nilai yang kecil menunjukkan nilai sensitivitas rendah. Menurut Arikunto (2009) butir soal dikatakan peka atau sensitif terhadap pembelajaran adalah mempunyai indeks sensivitas $\geq 0,30$.

\section{Lembar Penilaian Kemandirian}

Lembar penilaian kemandirian adalah lembar instrument yang dikembangkan untuk mengetahui sejauh mana tingkat kemandirian siswa selama mengikuti pembelajaran dengan menggunakan pendekatan keterampilan proses sains. Kemandirian siswa dinilai berdasarkan kriteria-kriteria yang diungkapkan Monks dalam Muna (1999), yakni memperlihatkan sikap percaya diri, mampu mengambil keputusan, mampu mengendalikan diri dan memiliki tanggung jawab yang tinggi dengan mengamati dan mencatat setiap keriteria yang muncul menggunakan istrumen.

7. Lembar Pengamatan Hambatan-hambatan Pembelajaran

Instrumen ini digunakan untuk mengetahui hambatan-hambatan yang ditemukan selama proses pembelajaran berlangsung serta solusi yang digunakan untuk mengatasi berbagai hambatan tersebut.

\section{HASIL PENELITIAN DAN PEMBAHASAN}

\section{A. Hasil Penelitian}

Penelitian ini menggunakan perangkat yang dikembangkan dan telah direvisi sesuai dengan saran validator. Pelaksanaan penelitian terbagi kedalam dua tahap, yaitu tahap pengembangan perangkat pembelajaran dan tahap implementasi. Implementasi perangkat pembelajaran dilakukan di SMP Negeri 1 Blega Bangkalan. Dalam hal ini peneliti bertindak sebagai guru selama empat kali pertemuan, pertemuan pertama dilakukan pretest untuk mengetahui kemampuan awal siswa, pertemuan kedua dan ketiga dilakukan proses pembelajaran, dan pertemuan keempat diadakan posttest yang bertujuan untuk mengetahui hasil belajar siswa setelah mengikuti kegiatan pembelajaran. Deskripsi hasil pengembangan perangkat pembelajaran dan implementasi 
perangkat pembelajaran dijabarkan pada subsub bab berikut ini.

\section{Pengembangan Perangkat}

Hasil Validasi pengembangan Perangkat secara singkat disajikan pada Tabel 1.

Tabel 1. Hasil Pengembangan Perangkat

\begin{tabular}{|l|l|c|}
\hline No & \multicolumn{1}{|c|}{ Perangkat } & Kategori \\
\hline 1 & $\begin{array}{l}\text { Rencana } \\
\text { Pelaksanaan } \\
\text { Pembelajaran }\end{array}$ & Baik \\
\hline 2 & $\begin{array}{l}\text { Lembar Kegiatan } \\
\text { Siswa }\end{array}$ & Baik \\
\hline 3 & Buku ajar & Baik \\
\hline 4 & Tes Hasil Belajar & Baik \\
\hline
\end{tabular}

Dari data diatas disimpulkan bahwa hasil Pengembangan Perangkat yang telah dikembangkan peneliti dapat digunakan sebagai perangkat pembelajaran dengan sedikit revisi.

\section{Penerapan Perangkat Pembelajaran}

Hasil Keterlaksanaan Pembelajaran dengan menggunakan pendekatan Keterampilan Proses Sains ditunjukkan pada Tabel 2.

Tabel 2. Rata-rata Penikian Keterbksanaan Rencana Pembebjaran dengan Pendekatan Keterampilan Proses Sains pada Pertemuan I dan II

\begin{tabular}{|c|c|c|c|c|c|}
\hline \multirow[b]{2}{*}{ No } & \multirow[b]{2}{*}{ Aspek yang Diamati } & \multicolumn{4}{|c|}{ Penilaian } \\
\hline & & P1 & $\mathbf{P} 2$ & \begin{tabular}{|c|} 
Shor \\
Rerata
\end{tabular} & Ket \\
\hline \multicolumn{6}{|c|}{ PENGAMATAN KBM } \\
\hline & A. Pendahuluan & & & & \\
\hline 1 & Inisiæi & 4,0 & 3,0 & 3,5 & $\mathrm{~B}$ \\
\hline 2 & Memberikan urientzi mæalah & 4,0 & 4,0 & 4,0 & $\mathrm{~B}$ \\
\hline \multirow[t]{2}{*}{3} & Menyampaikan Tujuan Pembelajaran & 4,0 & 4,0 & 4,0 & B \\
\hline & B. Kegitan Inti & & & & \\
\hline 4 & $\begin{array}{l}\text { Pembentukan dan pengembangann k匹 ep } \\
\text { dengan cara dis kus i kelđ }\end{array}$ & 3,0 & 3,0 & 3,0 & B \\
\hline 5 & $\begin{array}{l}\text { Mengag anisasikan siswa kedalam kelompak } \\
\text { belajar }\end{array}$ & 4,0 & 4,0 & 4,0 & $\mathrm{~B}$ \\
\hline 6 & $\begin{array}{l}\text { Membimbing s swa melakukan kegiatan } \\
\text { percabaan }\end{array}$ & 4,0 & 4,0 & 4,0 & B \\
\hline 7 & $\begin{array}{l}\text { Membimbing s iswa menganalis is dan membuat } \\
\text { kes impulan pada masing-mðing kelampak }\end{array}$ & 4,0 & 4,0 & 4,0 & B \\
\hline 8 & Membimbing s iswa menyeler aikan LKS & 4,0 & 4,0 & 4,0 & $\mathrm{~B}$ \\
\hline 9 & Membimbing dan mengarahkan s iswa berdis kus i & 4,0 & 4,0 & 4,0 & $\mathrm{~B}$ \\
\hline \multirow[t]{2}{*}{10} & Membimbings swa mereview hæil pembelajaran & 3,0 & 4,0 & 3,5 & $\mathrm{~B}$ \\
\hline & C. Penutup & & & & \\
\hline 11 & Evalusi & 4,0 & 4,0 & 4,0 & $\mathrm{~B}$ \\
\hline 12 & $\begin{array}{l}\text { Mengingatkan siswa untuk mempelajarimateri } \\
\text { selanjutnya. }\end{array}$ & 3,5 & 3,5 & 3,5 & $\mathrm{~B}$ \\
\hline \multicolumn{6}{|c|}{ SUASANA BELA.LAR } \\
\hline 1 & $\begin{array}{l}\text { Keresuaian KMB dengan Tujuan } \\
\text { Pembelajaran/IIndikatar }\end{array}$ & 4,0 & 4,0 & 4,0 & $\mathrm{~B}$ \\
\hline 2 & Penguðaan kansep & 3,0 & 4,0 & 3,5 & $\mathrm{~B}$ \\
\hline 3 & Guru antusiæ & 3,0 & 4,0 & 3,5 & B \\
\hline 4 & Síwa antusið & 3,0 & 5,0 & 4,0 & B \\
\hline 5 & KBM berpusat padaguru & 3,0 & 3,0 & 3,0 & $\mathrm{~B}$ \\
\hline 6 & KBM berpusat padas iwa & 5,0 & 4,0 & 4,5 & B \\
\hline
\end{tabular}

Keterangan :

SB : Sangat Baik,

B : Baik,

CB :Cukup Baik,

KB : Kuang Baik

Berdasarkan Tabel 2 dapat diketahui bahwa kemampuan guru mengelola KBM dengan pendekatan Keterampilan Proses Sains memiliki kriteria baik, karena memiliki nilai $\geq$ 3,5 . 


\section{Hasil Pengamatan Kemandirian Siswa}

Tabel 3. Hasil Analisis Kemandirian Siswa

\begin{tabular}{|l|c|c|c|c|c}
\hline \multirow{2}{*}{ No } & \multirow{2}{*}{ Nama siswa } & \multicolumn{2}{|c|}{$\begin{array}{c}\text { Persentasi kemandirian siswa } \\
\text { pada pertemuan ke- (\%) }\end{array}$} & \multirow{2}{*}{ Rata-rata } & $\begin{array}{c}\text { Kategori } \\
\text { kemandirian }\end{array}$ \\
\cline { 3 - 4 } & & $\mathbf{l}$ & $\mathbf{2}$ & & \\
\hline 1 & $\mathrm{Ar}$ & 72.22 & 83.33 & 77.78 & BAIK \\
\hline 2 & $\mathrm{Ak}$ & 72.22 & 72.22 & 72.72 & BAIK \\
\hline 3 & $\mathrm{Al}$ & 61.11 & 72.22 & 66.67 & BAIK \\
\hline 4 & $\mathrm{An}$ & 55.55 & 77.77 & 66.66 & BAIK \\
\hline 5 & $\mathrm{Af}$ & 77.77 & 88.88 & 83.32 & BAIK SEKALI \\
\hline 6 & $\mathrm{~Bq}$ & 66.66 & 77.77 & 72.21 & BAIK \\
\hline 7 & $\mathrm{Ds}$ & 66.66 & 72.22 & 69.44 & BAIK \\
\hline 8 & $\mathrm{Hm}$ & 66.66 & 61.11 & 63.89 & BAIK \\
\hline 9 & $\mathrm{Hn}$ & 61.11 & 61.11 & 61.11 & CUKUP \\
\hline 10 & $\mathrm{Ha}$ & 55.55 & 72.22 & 63.89 & BAIK \\
\hline 11 & $\mathrm{~b}$ & 66.66 & 61.11 & 63.89 & BAIK \\
\hline 12 & $\mathrm{If}$ & 72.22 & 83.33 & 77.78 & BAIK \\
\hline 13 & $\mathrm{Is}$ & 66.66 & 66.66 & 66.66 & BAIK \\
\hline 14 & $\mathrm{Km}$ & 72.22 & 72.22 & 72.72 & BAIK \\
\hline 15 & $\mathrm{Lq}$ & 66.66 & 66.66 & 69.44 & BAIK \\
\hline 16 & $\mathrm{Ls}$ & 72.22 & 66.66 & 69.44 & BAIK \\
\hline 17 & $\mathrm{Nh}$ & 61.11 & 72.22 & 66.67 & BAIK \\
\hline 18 & $\mathrm{Rn}$ & 61.11 & 77.77 & 69.44 & BAIK \\
\hline 19 & $\mathrm{Ra}$ & 72.22 & 88.88 & 80.55 & BAIK SEKALI \\
\hline 20 & $\mathrm{Rf}$ & 61.11 & 77.77 & 69.44 & BAIK \\
\hline 21 & $\mathrm{Sp}$ & 83.33 & 72.22 & 77.78 & BAIK \\
\hline 22 & $\mathrm{So}$ & 66.66 & 72.22 & 69.44 & BAIK \\
\hline 23 & $\mathrm{Sa}$ & 72.22 & 61.11 & 66.67 & BAIK \\
\hline 24 & $\mathrm{St}$ & 72.22 & 61.11 & 66.67 & BAIK \\
\hline 25 & $\mathrm{Sy}$ & 61.11 & 72.22 & 66.67 & BAIK \\
\hline 26 & $\mathrm{Su}$ & 55.55 & 61.11 & 58.33 & CUKUP \\
\hline 27 & Wr & 72.22 & 83.33 & 77.78 & BAIK \\
\hline 28 & $\mathrm{ya}$ & 66.66 & 66.66 & 66.66 & BAIK \\
\hline & & & & & \\
\hline
\end{tabular}

Berdasarkan tabel 3 dapat dikatakan bahwa rata-rata persentasi kemandirian siswa dari pertemuan 1 dan 2 bervariasi mulai dari 55.56 hingga 83.32 dengan kategori cukup hingga baik sekali. Berdasarkan hasil pengamatan ini, maka pembelajaran dengan menggunakan keterampilan proses sains dapat mengetahui atau melatih sejauh mana tingkat kemandirian siswa.

\section{B. PEMBAHASAN}

\section{Penerapan Perangkat Pembelajaran}

Berdasarkan hasil analisis data yang terlihat pada Tabel 2 di atas menunjukkan bahwa rata-rata sekor penilaian kedua pengamat terhadap keterlaksanaan rencana pembelajaran dengan pendekatan keterampilan proses sains dengan kategori rata-rata sudah baik, pada aspek kegiatan pendahuluan yang terbagi menjadi inisiasi dengan nilai rata-rata 3,5 kategori baik, memberikan orientasi masalah nilai rata-rata mencapai 4,0 dengan kategori baik, dan guru menyampaikan tujuan pembelajaran mencapai rata-rata 4,0 dengan kategori baik.

Aspek yang kedua adalah kegiatan inti yang terbagi menjadi beberapa tahap yakni pembentukan dan pengembangan konsep dengan cara diskusi kelas rata-rata nilai 3,0 hal ini berarti pada tahap pembentukan dan pengembangan konsep ini dapat diktegorikan baik, mengorganisasikan siswa kedalam kelompok belajar rata-rata nilai mencapai 4,0 dengan kategori baik, pada kegiatan mengorganisasikan siswa hanya dilakukan pada pertemuan pertama sedangkan untuk pertemuan selanjutnya atau kedua masih menggunakan kelompok yang pertama. Membimbing siswa melakukan kegiatan percobaan mencapai nilai rata-rata 4,0 dengan kategori baik, membimbing siswa menganalisis dan membuat kesimpulan pada masing-masing kelompok rata-rata nilai mencapai 4,0 dengan kategori baik, membimbing siswa menyelesaikan LKS nilai rata-rata 4,0 dengan kategori baik, membimbing dan mengarahkan siswa berdiskusi nilai ratarata 4,0 dengan kategori baik, dan membimbing siswa mereview hasil pembelajaran nilai ratarata mencapai 3,5 dengan kategori baik.

Aspek ketiga adalah aspek penutup dengan kegiatan mengevalusi dengan nilai rata- 
rata mencapai 4,0 dengan kategori baik, proses evalusi ini dilakukan untuk mengetahui seberapa besar kemampuan siswa dalam menangkap materi ajar yang telah disampaikan oleh guru. Bagian aspek yang dua adalah proses mengingatkan siswa untuk mempelajari materi selanjutnya dengan nilai rata-rata mencapai 3,5 dengan kategori baik. proses mengingatkan siswa untuk mempelajari materi selanjutnya hanya dilakukan pada pertemuan pertama sedangkan pada pertemuan kedua siswa hanya disarankan untuk belajar sebagai persiapan proses uji akhir postest.

Aspek suasana belajar yang terbagi menjadi beberapa kegiatan pengamatan antara lain kesesuaian KBM dengan tujuan pembelajaran atau indikator pembelajaran dari kedua pengamat mendapatkan nilai 4,0 dengan nilai rata-rata 4,0 berkategori baik. Pengamatan yang kedua adalah penguasaan konsep oleh guru pada saat proses pembelajaran berlangsung mencapai nilai rata-rata 3,5 dengan kategori baik, pengamatan yang ketiga adalah tentang antusias guru pada proses pembelajaran berlangsung dari kedua pengamat memberikan nilai yang berbeda yakni pengamat pertama memberikan nilai 4,0 dan pengamat kedua 4,0 dan nilai rata-rata mencapai 4,0 dengan kategori sangat baik. pengamatan ke empat mengenai antusias dari siswa nilai rata-rata mencapai 4,0 dengan kategori sangat baik, ke lima adalah KBM berpusat pada guru mencapai nilai 3,0 dengan kategori baik, dan KBM berpusat pada siswa mencapai 4,5 dengan kategori sangat baik.

\section{Hasil Pengamatan Kemandirian Siswa}

Berdasarkan data pada tabel 3 diperoleh informasi bahwa persentase rata-rata kemandirian siswa selama mengikuti pembelajaran antara $58.33 \%$ hingga $83.32 \%$ dengan kategori cukup baik hingga baik sekali pada aspek penilaian mulai dari sikap percaya diri, mampu mengambil keputusan, mampu mengendalikan diri, gigih, dan melakukan yang terbaik. Hasil ini menggambarkan bahwa karakter kemandirian siswa dapat dikembangkan melalui pendekatan Keterampilan Proses Sains.

Hasil temuan ini sejalan dengan apa yang disampaikan Asmani (2011), bahwa karakter dapat dikembangkan melalui tiga tahapan yaitu : Pengetahuan (knowing), pelaksanaan (acting), dan kebiasaan (habit). Hal ini diperlukan agar peserta didik dan warga sekolah yang terlibat dalam system pendidikan karakter dapat memahami, merasakan, menghayati dan mengamalkan (mengerjakan) nilai-nilai kebaikan. Pembelajaran yang melibatkan peserta didik sepenuhnya pada suatu aktifitas belajar, peserta didik didorong untuk melakukan rekleksi diri, bereaksi, menentukan akibat tindakan dan membuat keputusan yang relevan dengan situasi belajar. 
Carin (1993) menyatakan bahwa didalam pembelajaran keterampilan proses siswa dididik untuk lebih mandiri, mengarahkan diri mereka sendiri dan bertanggung jawab terhadap belajar mereka sendiri. Jika pembelajaran berbasis karakter ini terus dikembangkan dalam pembelajaran khususnya biologi, maka diharapkan terjadi proses internalisasi nilai-nilai kemandirian berlangsung dengan baik pada diri siswa, sehingga karakater kemandirian dapat terus dikembangkan.

Semakin besar tingkat kemandirian anak yang diberikan dalam pembelajaran, maka semakin besar kesempatan anak untuk melakukan proses internalisasi nilai-nilai mandiri kedalam dirinya sehingga akan berpengaruh pada kemandirian yang akan dimiliki oleh anak. Siswa cendrung mampuh memposisikan diri dalam situasi yang benar dan tepat. Siswa menjadi tahu apa yang harus dilakukan dengan cara yang benar karena pembimbing memberikan informasi yang jelas kepada siswa.

Asmani (2011) menyatakan yang harus ditekankan kepada para siswa adalah bahwa belajar mandiri bukan berarti belajar sendiri. Sering kali orang menyalahartikan belajar mandiri sebagai belajar sendiri. Kesalahan pengertian tersebut terjadi karena pada umumnya mereka memandang belajar mandiri lebih pada pengertian belajar sendiri tanpa teman belajar. Oleh karena itu, upaya menanamkan inisiatif dan kreatifitas siswa dalam belajar merupakan faktor penting yang harus dilakukan guru. Dengan demikian, pembimbingan yang intensif oleh guru dapat mengarahkan siswa menjadi lebih mandiri yang terarah.

Upaya meningkatkan kemandirian belajar merupakan jawaban dalam menghadapi tantangan maupun hambatan belajar bagi perkembangan siswa. Tantangan tersebut meliputi tantangan akibat perubahan-perubahan dan perkembangan segala aspek kehidupan. Orang Yunani berseru: "Kenalilah diri sendiri" artinya pribadi mandiri adalah dia yang tahu siapa dia dan apa yang harus dilakukan. Peningkatan kemandirian belajar siswa harus selalu diusahakan secara bersama baik oleh guru mata pelajaran maupun guru bimbingan konseling. Menurut Ryan dan Grolnick (dikutip Wong dan Dudley 2002), kemandirian yang diberikan oleh guru di dalam kelas dapat membuat siswa merasa bahwa dirinya memiliki kemampuan untuk mengerjakan tugas tugas akademis dan memiliki motivasi yang berasal dari dirinya sendiri.

Monks (1999) mengatakan bahwa orang yang mandiri akan memperlihatkan perilaku yang eksploratif, mampu mengambil keputusan, percaya diri dan kreatif. Selain itu juga mampu bertindak kritis, tidak takut berbuat sesuatu, mempunyai kepuasan dalam melakukan aktifitas, percaya diri, mampu menerima realitas serta dapat memanipulasi lingkungan, mampu berinteraksi dengan teman sebaya, percaya diri, terarah pada tujuan, dan mampu mengendalikan diri. Kemandirian yang 
dimiliki oleh siswa diwujudkan melalui kemampuannya dalam mengambil keputusan sendiri tanpa pengaruh dari orang lain.

Kemandirian juga terlihat dari berkurangnya ketergantungan siswa terhadap guru di sekolah seperti, pada jam pelajaran kosong karena ketidakhadiran guru di kelas, siswa dapat belajar secara mandiri dengan membaca buku atau mengerjakan latihan soal yang dimiliki. Siswa yang mandiri, tidak lagi membutuhkan perintah dari guru atau orang tua untuk belajar ketika berada di sekolah maupun di rumah. Kebutuhan untuk memiliki kemandirian dipercaya sebagai hal penting dalam memperkuat motivasi individu dan dapat diketahui bahwa siswa yang mandiri mampu memotivasi diri untuk bertahan dengan kesulitan yang dihadapi dan dapat menerima kegagalan dengan pikiran yang rasional.

\section{TEMUAN \& SIMPULAN}

\section{TEMUAN}

Berdasarkan hasil analisis data penelitian pengembangan perangkat pembelajaran biologi SMP pokok bahasan gerak pada tumbuhan dengan menggunakan pendekatan keterampilan proses sains di SMP Negeri 1 Blega bangkalan, ditemukan beberapa hal sebagai berikut:

1. Perangkat pembelajaran yang diperoleh meliputi Rencana Pelaksanaan Pembelajaran (RPP), Buku Siswa, Lembar Kegiatan Siswa (LKS), lembar pengamatan kemandirian siswa dan Tes Hasil Belajar (THB) dengan hasil validitas berkatagori baik namun dalam tahap penyusunannya mengalami berbagai revisi berdasarkan hasil telaah.

2. Keterlaksanaan pembelajaran menunjukkan kategori baik.

3. Kemandirian siswa dapat dilatih melalui pendekatan keterampilan proses sains, dan rata-rata persentase kemandirian siswa berpariasi mulai dari kategori cukup hingga baik sekali.

4. Aktivitas guru dalam kegiatan belajar mengajar berdasarkan analisis data nampak bahwa sebagian besar waktu dalam KBM digunakan guru untuk memotivasi, membimbing percobaan, mengecek pemahaman dan memberikan umpan balik.

5. Aktivitas siswa dalam kegiatan belajar mengajar berdasarkan analisis data nampak bahwa sebagian besar waktu KBM digunakan siswa untuk melakukan pengamatan/penyelidikan sehingga pembelajaran cendrung berpusat pada siswa.

6. Kemampuan kognitif siswa setelah melakukan pembelajaran dengan menggunakan pendekatan keterampilan proses sains terjadi peningkatan yang dilihat dari ketuntasan secara individual dan klasikal.

7. Respon siswa setelah mengikuti kegiatan pembelajaran dapat dikategorikan baik, mayoritas siswa menyatakan senang dengan kegiatan pembelajaran

8. Kendala-kendala yang diamati dalam proses implementasi pendekatan keterampilan 
proses sain adalah kurangnya pasilitas

seperti laboratorium dan alat-alat penunjang

lainnya.

\section{SIMPULAN}

Berdasarkan temuan hasil penelitian, dapat disimpulkan bahwa perangkat pembelajaran biologi yang berorientasi pada pendekatan Keterampilan Proses Sains efektif untuk meningkatkan prestasi belajar dan melatih Kemandirian siswa.

\section{DAFTAR PUSTAKA}

Arends, R.I. 2008. Learning to Teach. Belajar untuk Mengajar. Edisi ketujuh. Yogyakarta: Pustaka Pelajar.

Arikunto, S. 2009. Manajemen Penelitian. Jakarta: Bumi Aksara.

Asmani, J.M. 2011. Buku panduan internalisai pendidikan karakter disekolah. Jogjakarta : DIVA Press

Aunurrahman. 2009. Belajar dan Pembelajaran. Bandung: Alphabeta.

Bayer, Barry K. 1991. Teaching Thinking Skill : A Handbook for Elementary
School Teacher. New york, USA : Allyn \& Bacon

Borich, G.D. 1994. Observation Skills for Effective Teaching: Second Edition. New York: Macmillan Company, Inc.

Cain, E.S., and Evans, M.J. 1990. SCIENCING: An Involvement Approach to Elementary Science Methods. 3rd Editin. Colombus Toronto London Melbourne: Merrill Publishing Company.

Carin, A.A. 1993. Teaching Science Through Disccovery. New York: Macmillan Publishing Company.

Collete, T.A., and Chiappetta, L.A., 1994. Science Instruction in the Middle and Secondary Schools. New York: Macmillan Publishing Company.

Mulyasa, 2009. Implementasi Kurikulum Tingkat Satuan Pendidikan: Kemandirian Guru dan Kepala Sekolah. Jakarta: Bumi Aksara.

Mulyasa, 2006. Kurikulum Tingkat Satuan Pendidikan. Bandung: Rosda Karya.

Musrofi, M. 2010. Melesatkan prestasi Akademik Siswa. Yogyakarta : PT.Pustaka insan madani. 